Scveral pieces of pig iron were put into a ladle (holding about one ton of metal); these at first sank, and a rush of hot metal took place upwards; after a few seconds the pieces of pig iron appcared floaling, ivith very little of their bulk above the surface of the molten metal. A piece of flattish metal of irregular shape floated with a small portion alone of its corners above the surface; it was close to side of ladle. Pieces of flat cast-iron bars, $20^{\prime \prime} \times 2^{\prime \prime} \times 1^{\prime \prime}$, were carefully placed on surface (the latter being well skimmed); they floated without going below the surface. One of these pieces, which was put in end on, kept in this position for a few seconds, with its upper end above the surface; the other $€$ nd then came up and floated on its flat side. In some cases a sharp crack was heard when the metals touched, and a white flame on one occasion burned like a gas jet from the side of one of the pieces.

The surface of the molten metal was in constant motion due to the currents within its mass, and showed the variegated texture or "break" peculiar to this condition of the metal. From notes of an experiment which I arranged for, but did not see carried out, I find that a cast-iron ball of ahout $2 \frac{34^{\prime \prime}}{4}$ diameter, when lowered by a fine wire upon a well-skimmed surface of molten cast iron, disappeared completely at first, and then in a few seconds rose and floated with about half an inch diameter of surface exposed; it was then raised from the metal, when it showed a red glow on the lower part. It was again lowered, but now did not simk, but floated with about truice the surface exposed, as on the first experiment.

Different views are held as to the behaviour of cast iron when passing from the molten to the hot solid siate, and finally to the cold (or ordinary temperature) state.

Some hold that the molten metal, on solidifying, expands like water passing into ice, ard that it retains this expansion to such an extent that the cold colid is specifically lighter than the molten metal. Others hold that no such expansion takes place, and that finally the cold solid is specifically heavit $r$ than the molten metal. A third view is that the molten metal on solidifying expands, and that it then contracts during cooing, until it reaches ordinary temperature, when through the cooling it is specifically hectier than in the molten state.

From the fact that in foundry practice the linear contraction is taken at $\frac{1}{5}$ th part, there can be little doubt that the finally cooled solid is specifically heavier than the molten metal; again, from the sharpness of form of iron castings and other circumstances, expansion appears to take place on solidification.

The above experiments, $I$ think, favour this latter view, as the floating took place more ieadily with small than with large jieces, partly due to their relative bulks and surfaces.

A probable explanation, in part at least of these phenomena, I think, is that the cold metal, when at first put in, is specifically heavier than the molten metal, but owing to the great heat around it (uver $2,000^{\circ} \mathrm{F}$.) it is rapidly heated, and consequently expanded, and when sufficient volume has thus been obtained it floats. It is evident that small pieces, being more readily heated, may remain floatirg, whilst heavy pieces, whose volumes are larger in proportion to their surfaces, will take longer to heat, so as to induce the required change of volume, and may therefore at first sink, remaining below the surface till sufficiently expanded to rise and float. The experiment with the ball bears out this well, as, being a sphere, its surface was a minimum.

These experiments appear to corroborate very well those of your correspondent.

The following experiments which I lately made with lead may be of interest:- -

An ingot of lead of $\mathrm{r}_{4} \mathrm{lbs}$. weight was placed on the surface of about 160 lbs. of molten lead; it at once melted. After allowing the metal to cool a little, an ingot was carefully placed on the surface, when it immediately sank, bubbles rising up to the surface; it was heard to strike the bottom of the ladle. Another ingot was tried; it also sank, and could be felt at the bottom (these ingols were cast from the lead in the pot). A small solid piece was cast of about $\mathbf{I}_{\overline{2}} \mathrm{lb}$. weight, which also sank. Pieces of sheet leat were rolled up and placed on surface; these floated: the contained air and great surface in the latter would account for this.

These latter experiments with lead correspond very well with those of your correspondent with zinc. W. J. MIL.LAR Glasgow

\section{Yellow Crocuses}

IN my garden the sparrows do pnot touch the crocuses. In that of a friend, some miles off, they attack the yellow ones exclusively. I address you chiefly to report a fact related to me by the vicar of a neighbouring parish, whose garden is infested with mice. He tells me that for some time he thought he could not grow crocuses at all, as the mice destroyed the corms, discovering and digging down to them, even when there was no trace of the plants on the surface. At last he found that they dicl not attack the purple crocus, and on his planting the edge of a long border, with alternate clumps of yellow and purple crocuses, the mice almost entirely destroyed all the clumps of yellow, but left the purple untouched. Possibly the purple plant possesses some acrid or bitter taste, rendering it nauseous to animals - the corms to mice, the flowers to sparrows and other birds.

Newton-le-Willows, May 4

THOMAS COMBeR

\section{Hog-Wallows and Prairie Mounds}

If Mr. Williams is right, and the "hog.wallows" are simply American cousins of our "eshars" or "kames," is it not rea. sonable to credit that "atmospheric erosion" to which Prof. Le Conte attributes the formation of the former with a much more important influence upon the shapes of the latter than British geologists generally seem disposed to accord to it? It is very difficult to conceive that mounds of loose sand and gravel, whether in valleys or on plains, should have retained the impress of the glacier or the iceberg throughout the vast time that must have elapsed since these phenomena entirely disappeared. Aud if it be conceded that these mounds have been modified in any degree by subaërial denudation, it will be found difficult to limit the extent to which they are indebted to it for their present forms, or indeed to deny that it alone may have shaped them.

Newport, Fife, May 7 JAS. DURHaAt

\section{A. "Golden Bough"}

IN the gardens of New College, Oxford, there is a fine avenue of horse-chestnut trees, most of which have had some of theit lower limbs lopped off, followed by the usual crop of abundant smaller shoots around the original bough. In one tree, however, with respect to one severed branch, these resultant shoots bear, year after year, not green, but pale jellow leaves, the summer through-

$$
\begin{aligned}
& \text { "Primo avulso non deficit alter } \\
& \text { aureus, et simili frondescit virga metallo." }
\end{aligned}
$$

It would be interesting to know of other instances of such a veritable "golden bough," and whether any explanation can be given of chlorophyll so remarkably failing to develop its bluegreen constituent under no obviously peculiar circumstances, It seems a strange anomaly to find in apparent case of host and saprophyte in one. HENRY T. WHARTON

\section{SPONTANEOUS GENERATION}

ON Friday evening last the Rev. W. Ir. Dallinger made an important communication to the members of the Royal Institution on "Recent Researches into the Origin and Development of Minute and Lowly Life-forms; with a Glance at the Bearing of these on the Origin of Bacteria." Biological Science to-day presents us with a magnificent generalisation; and that which lies within it and forms the fibre of its fabric, is the estab. lishment of a continuity--an unbroken chain of unity-running from the base to the apex of the entire organic series. 13ut does this imposing continuity find its terminus on the fringe and border of the organic series, and for ever pause there? or, can we see it pushing its way down and onward into the unorganised and the not-living, until all nature is an unbroken sequence and a continuous whole? That such a sublime continuity may be philosophically hypothecated is to be believed. But that data have been presented to us demonstrating how and by what path the inorganic passes to the vital, the living into the not-living, may be denied. The properties of living matter distinguish it absolutely from all other kinds of things, and the facts tu-day in the hands of the biologist furnish us with no link between the living and the not-living. This is an inference which has been fiercely disputed.

But what are the nature of the proofs relied upon to establish the "spontaneous" or not living origin of living things? They were chiefly thermal experiments upon the lowest septic organisms, without an attempt to discover what was their life history, and whether they propagated by germs or not. It was. argued that the adult organisms being killed at a given temperature much below the boiling point of water, if an infusion were boiled with every possible precaution, and whilst boiling her- 
metically sealed, and after a lapse of time on opening the vessel the organisms were found in a living state, they must have arisen de novo. That is, the not living would have produced the living ; that this method is useful, and that it must be pursued in an exhaustive inquiry into the whole subject, must be freely admitted. But that it is the best, or at least the only, method of inquiry for the biologist we may gravely doubt.

Ten years ago Mr. Dallinger determined to endeavour to work out by actual microscopic observation the life history of some of the lowly life forms.

After four years spent in preparation he commenced his work in conjunction with Dr. Drysdale, the plan needing two observers. A characteristic feature of the work was that each set of observations should be made absolutely continuous, so that nothing should have to be inferred. An arrangement was made by which the little drop of septic fluid cortaining the objects under examination should be free from evaporation, and very high powers were employed. The largest adult objects included in the examination were the one-thous andth of an inch, the smallest adults were the four-thousandth. Six forms altogether were selected, and, by long, patient, and unbroken watching, their whole history was worked out. While reproduction by fission seemed at first to the observers to be the usual method, prolonger research made knnwn that spores were produced. These were so small that a m inifying power of 5,000 dianeters was needed to see them as they began to grow. The glairy fluid from which they developed seemed at hist homogeneous, and it was only when growth set in that the spores became visible. All that could be learnt about the origin of the glairy fluid was that a monad, larger than usual, and with a granulated aspect towards the flagellate end, would seize on one in the ordinary condition. The two would swim about together till the larger absorbed the smaller, and the two were fused together. A mo. tionless spheroidal glossy speck was then all that could be seen. This speck was found to be a sac, and after remaining still for from ten to thirty-six hours it burst, and the glairy homogeneous fluid flowed out. The young spores that came into view in this were watched through to the adult condition. Bearing on the subject of spontaneous generation, this fact was learnt, that while a temperature of $140^{\circ} \mathrm{F}$. was sufficient to cause the death of adults, the spores were able to grow even after having been heated to $300^{\circ} \mathrm{F}$. for ten minules. Can it be philosophical, Mr. Dallinger asked, with the life history of bacteria still unknown, to assume it as a different method of propagation? Some experiments based on Prof. Tyndall's use of the electric beam to test optica ally pure air were made. The remains of infusions known to contain certain spores were diffused through glass tubes, in which were placed vessels with fluid. Monads always appeared in the fluids, but when after the air in the tubes had been allowed to purify itself by settlement, fresh fluids were introduced, no monads appeared. That there is no such thing as spontaneous generation of monads seems quite clear, and when bacteria are in like manner studied, there can be hardly a doubt the same law will be found to hold good with them.

\section{GREAT GUNS}

$T$ is natural that at the present time great interest should be taken in all efforts to improve, that is, to render more destructive, our implements of war. Even since the last war on the European field great advances have been made in this direction; and, as our readers know, one of the largest guns ever constructed is at present on its trial in this country. Some months ago experiments were made with what is known as the $8 \mathrm{I}$-ton gun, the invention of Mr. Robert Fraser; the gun was sent back to Woolwich for some alterations to be made, and on Friday the experiments were resumed at Shoeburyness on a larger scale. On the previous occasion the gun was loaded with 370 lbs. of powder, and threw a blind Palliser shell against the target. This target is of enormous strength, as strong and firmly founded as the ingenuity of engineers can make it. It is formed of four plates of the best rolled iron, each plate being 8 inches thick, and 5 inches of solid teak filled up each of the three intervals between the four plates. The 32 inches of iron and 15 inches of teak thus placed are solicliy screwed together by bolts 3 inches in diameter, the whole forming, as far as scientific engineers and artillerists could construct it, an apparently impenetrable and immovable mass. To secure the target still more, iron plates were placed on the top and at the side, those at the side being strutted against the target with heary timbers; and the supports at the rear of the target, to hold is up, as it were against any blow, were of the like solid and substantial character.

The target stood at r2o yards' distance from the gun. On Friday the charge of powder was $425 \mathrm{lbs}$, and the weight of the blind Palliser shell 1,700 1bs. At the base of the latter was an expanding copper-ridge, known as the "Lyon" gas-check, which in the explosion would expand and fill the rifling, thus enabling the full energy of the exploded powder to be utilised.

After the gun was fired, by electricity, it was examined and found to have worked admirably; it had run back 55 feet on its tramway, which rises slightly, and had run down again to the firing point. The shot was found not only to have penetrated three plates and the teak intervals to all four, as on the previous occasion, but to have bulged out the fourth plate some 15 inches from its normal position. The last plate was, moreover, broken across, the edges of the broken part gaping wide, and showing the head of the shot, which hat thus penetrated further in distance than the 47 inches of iron and teak of the targer. The powerful framework behind the target was greally shaken. The shot itself had "set-up," i.e., closed towards the head with the enormous energy, the rear-part, the gun-metal studs, and the copper gas-check, crumbling into pieces. The initial velocity of the shot, as registered by $M$. Le Boulenger's invention of wires with electric communication was $I, 600$ feet a second, and the striking velocity 5,585 teet. The mean pressure on the gun was found to be 20 tons, the interior remaining quite unaltered.

Herr Krupp, the well-known Prussian artillerist, has been devising a weapon even more formidable than that whose power of destruction was shown on Friday to be so immense, The Fraser gun is of wrought iron, but the new Krupp gun is of cast-steel, both being very nearly of the same weight, though the latter has the great advantage over the former of being a breech-loader. "The length of the gun, including the breech-picce, is 29 reet 6 inches, the breech-piece itself being 6 feet 4 inches in lenth. The calibre of the gun is 15 inches. The weight of the projectile will be 750 kilogrammes, or 1,650 lbs, and the powder charge will be 395 los. The external diameter of the Krupp gun, independentily of a narrow strengthening ring at the extreme rear, is 5 feet Io inches, that of the Fraser gun being 6 feet. The core of the Krupp gun is a steel tube in two lengths, upon which four steel rings overlap, rising in steps from a point between the muzzle and the trunnions, and accumulating in the thickness towards its rear. These more massive rings are irrespective of the narrow strengthening ring over the powder chamber. The external diameter of the gun at the muzle is 2 feet $3 \frac{1}{2}$ inches.

In common with the other large Krupp guns, the rifling of the new weapon is on the polygroove system, the elongated projectile being rotated by means of the gas-check. The velocity anticipated from the projectile tired from. the Krupp 8o-ton gun is 473 metres per second at the muzzle, or 1,552 feet, producing an energy of 27,543 foot tons, equal to 556 foot tons per inch of shot's circumference.

But this is not all. Should the demand arise, the great Prussian gun-maker has a design already prepared for a gun of 124 tons, to be made on the same plan as the one just described. The larger weapon would have a calibre slightly exceeding 18 inches, and would throw a steel shell weighing $\mathrm{I}, 000$ kilogrammes, or a chilled iron shell of 1,030 kilogrammes. 'The weight of the projectile would therefore be practically a ton, and the charge of powicr? will be probably about 500 pounds. 